\title{
Modern treatment of heart failure
}

\section{Diuretics are often enough, but do not overuse}

In heart failure a compensatory increase in atrial pressures helps maintain the cardiac output. Venoconstriction mediated by the sympathetic nervous system redistributes blood flow centrally, and activation of the renin-angiotensin system stimulates salt and water retention.' These same neuroendocrine mechanisms increase vascular resistance, which supports the blood pressure but also creates a vicious cycle of increasing left ventricular afterload and falling cardiac output. ${ }^{2}$ Raised atrial pressures and reduced cardiac output, expressed clinically as pulmonary and systemic congestion and peripheral hypoperfusion, cause the dyspnoea, oedema, and fatigue of heart failure. Dyspnoea is worse on exertion or lying flat (both of which provoke a steep rise in the left atrial pressure) and is often accompanied by fatigue if cardiac output is inadequate for the oxygen requirement of the exercising muscle. Logically therefore the treatment of heart failure should aim at lowering atrial pressures and improving cardiac output.

Diuretics are the first drugs to use, and often no other treatment is necessary. They promote excretion of salt and water, reducing the plasma volume and atrial pressures. This corrects pulmonary and systemic congestion and improves both the capacity for exercise and peripheral oedema. ${ }^{34}$ Diuretics do not, however, improve cardiac output. Indeed, by reducing preload they may reduce cardiac output: overuse of diuretics must thus be avoided.

In stimulating the renin-angiotensin system diuretics may exacerbate the vicious cycle of increasing vascular resistance and falling cardiac output. ${ }^{45}$ This provides a rationale for combining diuretics with angiotensin converting enzyme inhibitors, which block the synthesis of angiotensin II, reduce vascular resistance by vasodilatation, and break the cycle. The improvement in cardiac output is associated with reductions in atrial pressures caused by venodilatation and enhanced excretion of salt and water ${ }^{6-8}$ Thus used with diuretics converting enzyme inhibitors reduce fatigue and dyspnoea and improve the capacity for exercise. ${ }^{9}$

Conventional vasodilators such as nitrates, prazosin, and hydralazine also reduce atrial pressures and improve cardiac output. ${ }^{10}$ Tolerance, however, is common, and the capacity for exercise rarely improves. ${ }^{112}$ This may reflect the unfavourable neuroendocrine effects of these drugs (including stimulating both the sympathetic and renin-angiotensin systems.), which tend to intensify vasoconstriction and fluid retention and counteract the early benefits of treatment. ${ }^{13}$
Thus conventional vasodilators are less effective than converting enzyme inhibitors for treating heart failure and are now rarely used..$^{14} 15$

Inotropic stimulation also improves cardiac output, and digitalis remains the only agent licensed for clinical use, although several new oral agents are being investigated. ${ }^{16}$ Digitalis is the best drug for controlling heart rate in atrial fibrillation, but in sinus rhythm the responses are barely palpable - and the narrow therapeutic range makes the ratio of risk to benefit too high for most patients. ${ }^{17}$ Whether the new oral catecholamines and phosphodiesterase inhibitors will prove more effective remains to be seen. To date controlled trials have failed to identify a clinical role for any of themexcept for xamoterol (a $\beta_{1}$ partial agonist), which may be helpful in mild to moderate heart failure. ${ }^{18}$

There is increasing concern that some treatments for heart failure worsen prognosis. Neuroendocrine activity reflects the severity of heart failure, and further increasing circulating catecholamine concentrations and stimulating the reninangiotensin system with $\beta$ adrenergic agonists has not proved effective in controlled trials. ${ }^{16}$ Indeed, some of the newer inotropic drugs have been associated with a disturbingly high mortality, ${ }^{19}$ which may be caused by arrhythmias or the acceleration of myocardial cell death if oxygen demand becomes excessive. ${ }^{20}$ Neuroendocrine antagonists, in contrast, seem to improve survival. ${ }^{21}$ Evidence is best for converting enzyme inhibitors, ${ }^{22}$ but $\beta$ blockers, though negatively inotropic, may help patients able to tolerate them. ${ }^{23}{ }^{24}$ How neuroendocrine antagonists improve survival is not clear; possible mechanisms include improving myocardial energy balance and perfusion of vital organs and preventing cardiac arrhythmias. About half of all deaths from heart failure occur suddenly suggesting that antiarrhythmic drugs may be important prophylactically. ${ }^{25}$

A reasonable management strategy for patients with heart failure is first to identify and if possible correct the cause. Aggravating factors, particularly arrhythmias and hypertension, should also be corrected. Further treatment is aimed at controlling symptoms and slowing the progression of the disease. Diuretics are the first drugs to use, but if patients require more than $40 \mathrm{mg}$ a day of frusemide (or its equivalent) a converting enzyme inhibitor should be added. I recommend a low dose initially (captopril $12.5 \mathrm{mg}$ or enalapril $2.5 \mathrm{mg}$ twice daily), which may be increased if blood pressure and renal function remain satisfactory. As heart failure worsens 
inotropic stimulation should be considered. Digitalis is unlikely to be effective, but a short term infusion of dobutamine often produces sustained improvement for several weeks; the treatment may then be repeated. ${ }^{26}{ }^{27}$ Once heart failure has become this severe, however, prognosis is poor, and heart transplantation becomes the only treatment likely to work.

ADAM D TIMMIS

Consultant Cardiologist,

Newham General Hospital,

London E13 8SL

1 Francis GS, Goldsmith SR, Levine TB, Olivari MT, Cohn JN. The neurohumoral axis in congestive heart failure. Ann Intern Med 1984;101:370-7.

2 Kluger J, Cody RJ, Laragh JH. The contributions of sympathetic tone and the renin-angiotensin system to severe chronic congestive heart failure: response to specific inhibitors (prazosin and captopril). Am J Cardiol 1982;49:1667-74.

3 Stampfer M, Epstein SE, Beiser GD, Braunwald E. Hemodynamic effects of diuresis at rest and during intense upright exercise in patients with impaired cardiac function. Circulation 1968;37:900-11

4 Bayliss J, Norell M, Canepa-Anson R, Sutton G, Poole-Wilson P. Untreated heart failure: clinical and neuroendocrine effects of introducing diuretics. Br Hearl 7 1987;57:17-22.

5 Ikram $\mathrm{H}$, Chan W, Espiner EA, Nicholls MG. Haemodynamic and hormone responses to acute and chronic frusemide therapy in congestive heart failure. Clin $S$ ci 1980;59:443-9.

6 Kramer BL, Massie BM, Topic N. Controlled trial of captopril in chronic heart failure: a rest and exercise hemodynamic study. Circulation 1983;67:807-16.

7 Captopril Multicenter Research Group. A placebo-controlled trial of captopril in refractory chronic congestive heart failure. 7 Am Coll Cardiol 1983;2:755-63.

8 Cleland JGF, Dariie HJ, Hodsman GP, et al. Captopril in heart failure. A double blind controlled trial. Br Heart f 1984;52:530-5.

9 Packer M, Lee WH, Yushak M, Medina N. Comparison of captopril and enalapril in patients with severe chronic heart failure. $N$ Engl f Med 1986;315:847-52.
10 Chatteriee K, Parmley WW. Vasodilator therapy for acute and chronic heart failure. Br Heart $\mathcal{f}$ 1977;39:706-20

11 Packer M, Meller J, Gorlin R, Herman MV. Hemodynamic and clinical tachyphylaxis to prazosinmediated afterload reduction in severe chronic congestive heart failure. Circulation 1979;59:531-9.

12 Franciosa JA, Weber KT, Levine TB, et al. Hydralazine in the long-term treatment of chronic heart failure: lack of difference from placebo. Am Heart f 1979;59:531-9.

13 Colucci WS, Williams GH, Alexander RW, Braunwald E. Mechanisms and implications of vasodilator tolerance in the treatment of congestive heart failure. $A m$ J Med 1981;71:89-99.

14 Bayliss J, Norell MS, Canepa-Anson R, Reid C, Poole-Wilson P, Sutton G. Clinical importance of the renin-angiotensin system in chronic heart failure: double blind comparison of captopril and prazosin. Br Med F 1985;290:1861-6.
pre renin-angiotensin system in chronich

15 Packer $M$. Medina N, Yushak M. Comparative hemodynamic and clinical effects of long-term treatment with prazosin and captopril for severe chronic congestive heart failure secondary to coropary artery disease or idiopathic dilated cardiomyopathy. Am 7 Cardiol 1986;57: 1323-7.

16 Timmis AD. Inotropic drugs for the treatment of congestive heart failure: future prospects

Br Heart f (in press).
17 Chamberlain DA. Digitalis: where are we now? Br Hearl f 1985;54:227-33

18 The German and Austrian Xamoterol Study Group. Double-blind placebo-controlled comparison of digoxin and xamoterol in chronic heart failure. Lancet 1988;i:489-93.

19 Packer M, Leier CV. Survival in congestive heart failure during treatment with drugs with positive inotropic actions. Circulation 1987;75 (suppl IV): $55-63$

$20 \mathrm{Katz}$ AM. Potential deleterious effects of inotropic agents in the therapy of chronic heart failure. Circulation 1986;73 (suppl III): 184-90

21 Packer M, Lee WH, Kessler PD, Gottlieb SS, Bernstein JL, Kukin ML. Role of neurohormonal mechanisms in determining survival in patients with severe chronic heart failure. Circulation 1987;75 (suppl IV):80-92

22 The Consensus Trial Study Group. Effects of enalapril on mortality in severe congestive heart failure. Results of the Cooperative North Scandinavian Enalapril Survival Study (CONSEN SUS). N Engl I Med 1987;316:1429-35.

23 Swedberg K, Hjalmarson A, Waagstein F, Wallentin I. Prolongation of survival in congestive cardiomyopathy by beta-receptor blockade. Lancet 1979;1:1374-6.

24 Anderson JL, Lutz JR, Gilbert EM, et al. A randomized trial of low-dose beta-blockade therapy for idiopathic dilated cardiomyopathy. Am f Cardiol 1985;55:471-5.

25. Cleland JGF, Dargie HJ, Ford I. Mortality in heart failure: clinical variables of prognostic value. Br Heart F 1987;58:572-82.

26 Liang C-S, Sherman LG, Doherty JU, Wellington K, Lee VW, Hood WB Jr. Sustained improvement of cardiac function in patients with congestive heart failure after short-term infusion of dobutamine. Circulation 1984;69:113-9.

27 Applefeld MM, Newman KA, Grove WR, et al. Intermittent, continuous outpatient dobutamine infusion in the management of congestive heart failure. Am $\mathcal{J}$ Cardiol 1983;51:455-8.

\section{Primary health care for the single homeless}

\section{Many special schemes}

Last year was the international year of the single homeless, but the problem of how best to provide health care for this group is still far from solved. The central question is whether to set up special services or to encourage them to use the services that exist for the general population.

Some of the single homeless are neither single nor homeless but most are to be found in inner cities. The government's own report on the single homeless concluded that they were a heterogenous population characterised by lacking family support and independent accommodation. Most live in cheap lodging houses and hostels, but some have no fixed abode. Counting them is difficult, but 30000 were identified as living in hostels in $1974 .^{2}$ The numbers are likely to have increased since then. Compared with the rest of the population the single homeless have increased health care needs ${ }^{34}$ but use the health care services less. ${ }^{5}$ They consult general practitioners mostly with chronic handicapping conditions. ${ }^{6-8}$ Most do not register with a general practitioner, ${ }^{9}$ and many who do attend only when their condition is advanced. Alternatively, they may attend a local hospital accident and emergency department. ${ }^{11} 11$

There have been many attempts to provide for the single homeless health care facilities that do not depend on the initiative of the individual to seek care. Present discussion centres on appointing special salaried general medical practitioners $^{15}$ or nurse practitioners. ${ }^{16}$ These schemes operate outside the normal NHS and therefore may be seen as increasing the social isolation of the single homeless. Some have thus argued that it is better to reintegrate services for the single homeless into the normal primary care services. ${ }^{17}$

Primary health care services for the single homeless have been provided through a single handed practitioner in Manchester and through dedicated "house doctors" to the hostels for the single homeless in Edinburgh. These schemes have aimed at promoting the reintegration of the single homeless with the general primary care services, and in Edinburgh the proportion of the single homeless hostel dwellers registered with general practitioners increased from $32 \%$ in 1974 to $88-90 \%$ in 1986 . The same is thought to have happened in Manchester, although exact figures are not yet available. These schemes have also encouraged the single homeless actually to use the services. In Edinburgh the annual consultation rate for the single homeless with the general practitioners in the scheme was 3.19 compared with 3.33 for men aged 25 or more and 3.83 for women aged 25 or more in the general population. ${ }^{19}$ At the same time the "appropriateness" of consultations of the single homeless at an accident and emergency department was $57 \%$ for those known to the primary health care team, $29 \%$ for those outside the scheme, and $75 \%$ for the general population.

Existing services for the hostel dwellers now need to be extended to the growing population of single homeless in bed and breakfast accommodation and to the migrant population sleeping rough or travelling throughout the country. The current pilot schemes for salaried practitioners for the single homeless have yet to be evaluated, but they have anyway been promoted only as a temporary measure. Even so there has been widespread opposition to such appointments among doctors. Whatever services are developed for the single homeless the planning process must consider the acceptability of the service to both providers and recipients. ${ }^{19}$ The use of services by the single homeless requires further study, and access difficulties remain largely unquantified. It is also necessary to recognise the increased workload for the primary care services posed by this population. The growing awareness of health authorities about the health care needs of the 